\title{
DESIGN, DEVELOPMENT AND FABRICATION OF A LOW COST CORN DESEEDING MACHINE
}

\author{
Anant J. Ghadi ${ }^{1}$ and Arunkumar $\mathbf{P}^{\mathbf{2}}$ \\ ${ }^{1}$ Assistant Professor, Department of Mechanical Engineering, MMEC, Belgaum, Karnataka, India \\ ${ }^{2}$ Associate Professor, Department of Mechanical Engineering, KLS GIT, Belgaum, Karnataka, India
}

\begin{abstract}
Maize, known in many English-speaking countries as corn, is a grain domesticated by indigenous people in prehistoric times. The Aztecs and Mayans cultivated it in numerous varieties throughout central and southern Mexico, to cook or grind in a process called nixtamalization. The crop spread throughout America and later around the 1250 BC it spread to all corners of the region. Any significant or dense populations in the region developed a great trade network based on surplus and varieties of maize crops. After European contact with the Americas in the late 15th and early 16th centuries, explorers and traders carried maize back to Europe and introduced it to other countries through trade. Maize spread to the rest of the world due to its popularity and ability to grow in diverse climates.
\end{abstract}

The existing methods of corn de-husking in agriculture industry consist of breaking the grains by hand or by using large machinery for deseeding, both of which are not effective for a developing economy like India where farmers have little money for investment. Hence there is a need for an innovative idea or product that is feasible, safe, cost effective and productive for the Indian farmer.

Keywords: corn, teeth, drum.

\section{INTRODUCTION}

In today's industrial world man's innovative ideas has taken him towards all directions concerning about the production and safety in industrial establishments. Some instruments are of shear excellence where as others are the result of long research and persistent work, but it is not the amount of time and money spend in the invention of device or the sophistication of it operation is important, but its convenience, utility and operational efficiency that are important in considering the device.

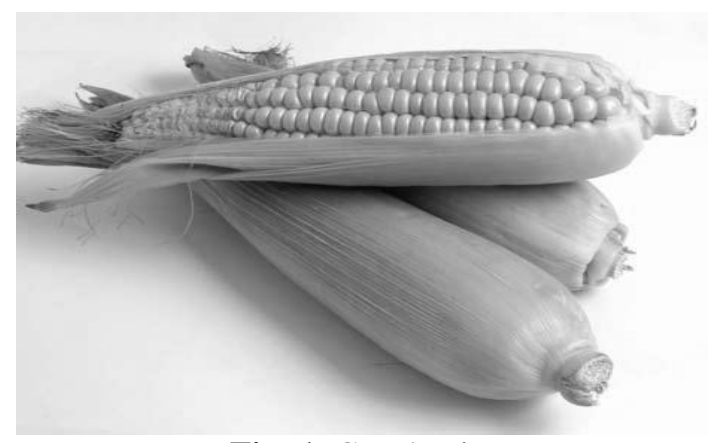

Fig -1: Corn/Maize

De-seeding of corn is the process of removal of its inner layers, leaving only the cob or seed rack of the corn. Deseeding is the process of removing the hulls (or chaff) from beans and other seeds. This is sometimes done using a machine known as a huller. To prepare the seeds to have oils extracted from them, they are cleaned to remove any foreign objects. Next, the seeds have their hulls, or outer coverings, or husk removed [1].

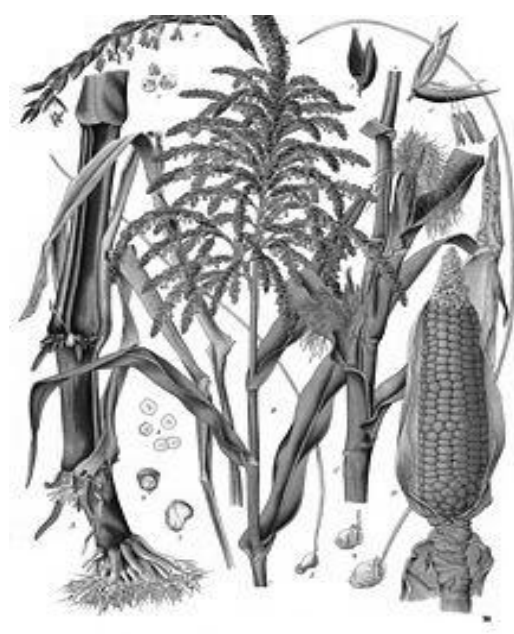

Fig -2: Different corn types

There are three different types of De-seeding systems that can be used to process soybeans: Hot De-seeding, Warm De-seeding and Cold De-seeding. Hot De-seeding is the system offered in areas where beans are processed directly from the field. Warm De-seeding is often used by processors who import their soybeans. Cold De-seeding is offered to plants that have existing drying and conditioning equipment, but need to add De-seeding equipment to produce high protein meal. The different De-seeding temperature options are for different types of production, beans and preparation equipment. 
A huller, husker or de-seeder is an agricultural machine used to automate the process of removing the chaff and the outer husks of grain. Throughout history, there have been numerous techniques to hull rice. In more recent times the processes are mechanized, and the machine is called a huller, or rice huller. These machines are most widely developed and used throughout Asia.

The idea is to shake grains and have them collide and scratch each other and container-walls, thereby loosening the outer husk and then blowing the lighter husk away. Other methods pass the grains between rubber rolls or other soft material, this is often less damaging to the grains.

Some of the corn specific de-seeders have been discussed below.

Amisy Machinery manufactures corn deseeding machine which is made of stainless steel. The machine has the wheels to move easily. The exit parts of the machine have the fan to get out of the waste. It comes with a $2 \mathrm{hp}$ motor. The output of the machine is $600 \mathrm{~kg} / \mathrm{hr}$. The cost is approximately Rs $3,00,000[2]$.

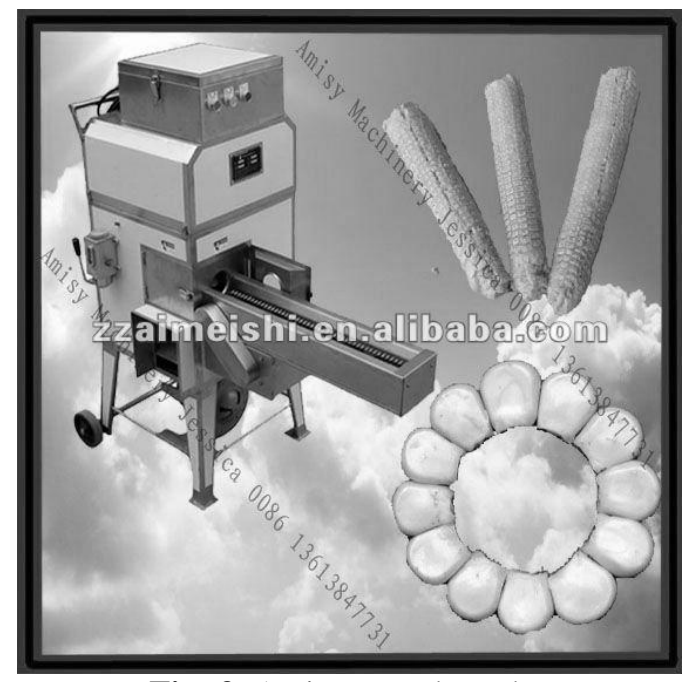

Fig -3: Amisy corn deseeder

Vidhata maize sheller (as shown in fig ) is used for shelling maize. The machine is quite simple in construction and provided with three point linkage and pto arrangement. It is very easily transportable as it is a tractor operated machine with a $10 \mathrm{hp}$ motor and drum size of $3 \mathrm{ft}$. The output of the machine is $5000 \mathrm{~kg} / \mathrm{hr}$. The maize cobs are put into hopper from where they go into drum in which shelling disk is mounted. Shelling is accomplished by the rotation of disc. Blower and double movable sieve separate the foreign matters from kernels. The cost is approximately Rs $1,20,000$.

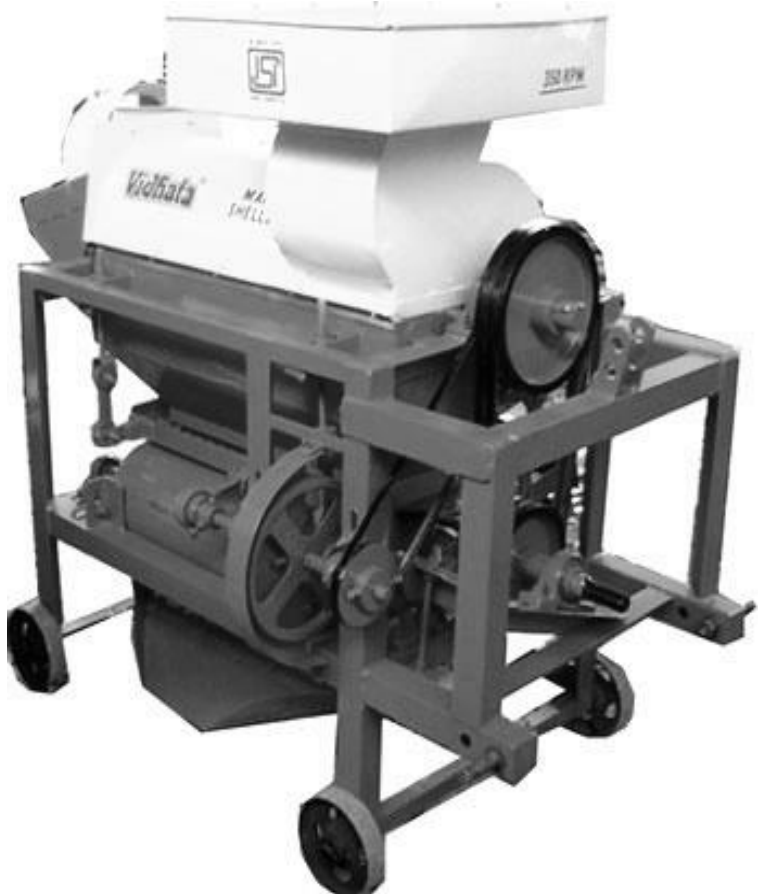

Fig -4: Vidhata Maize sheller

Vidhata manufactures another lower capacity maize sheller (as shown in fig ) is used for shelling maize. The machine is quite simple in construction and made out of steel angles. It is easily transportable with a $5 \mathrm{hp}$ motor and drum size of $2.5 \mathrm{ft}$. The output of the machine is $2000 \mathrm{~kg} / \mathrm{hr}$. It has a well balanced drum mounted on aligned roller bearing. Fan is provided to clean small dust \& other foreign particles. The cost is approximately Rs 72,000 [3].

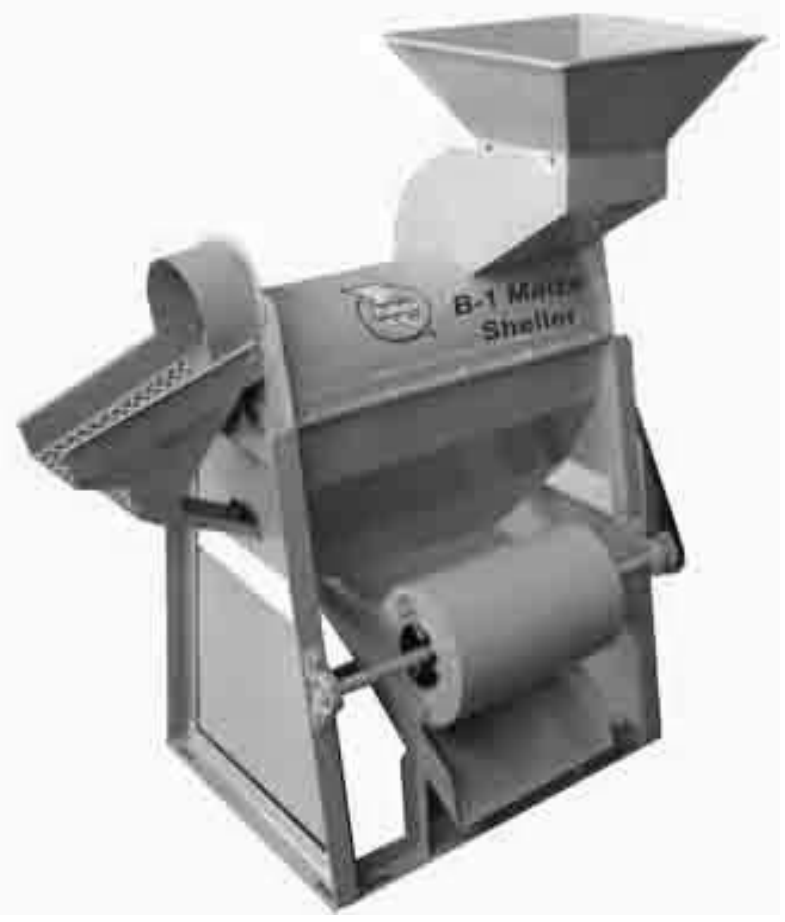

Fig -5: Vidhata Maize sheller 


\section{CORN DE-SEEDING MACHINE DESIGN AND}

\section{DEVELOPMENT}

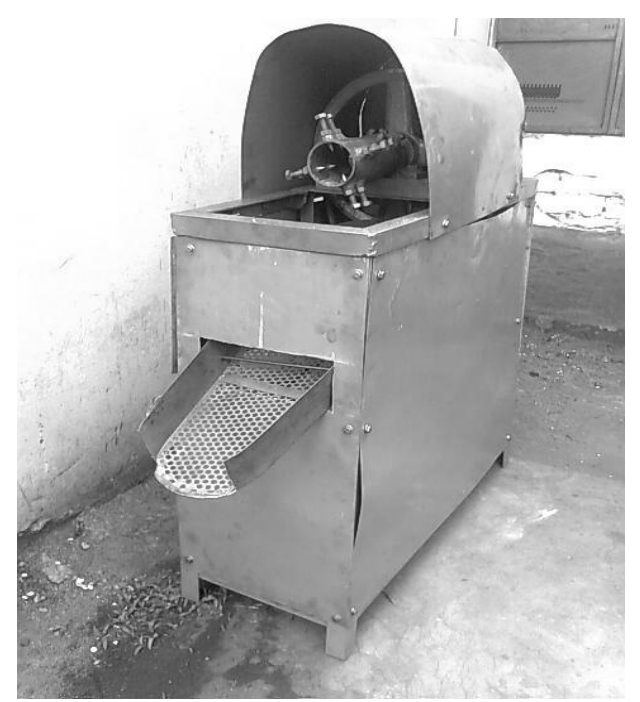

Fig -6: Corn deseeding machine

\subsection{Parts}

The device is simple in operation consisting of following parts

$\begin{array}{ll}\text { - } & \text { Stand } \\ \text { - } & \text { Motor } \\ \text { - } & \text { Screener } \\ \text { - } & \text { Main head } \\ \text { - } & \text { Belt } \\ \text { - } & \text { Phaft } \\ \text { Pulleys }\end{array}$

The working of the corn de-husking machine is simple in operation which is made up of cast iron angles stand in order to resist the whole load of the machine or the device. A plate is welded to the stand angles where the motor is mounted or rested. The motor is attached with the pulley where the motion from the motor is transmitted with the help of belt to the main shaft \& as a result the shaft rotates. Corn is fed manually through the main head and as a result corn grains are separated from the cub which can be easily de-seeded.

\section{DESIGN AND CAD DRAWINGS}

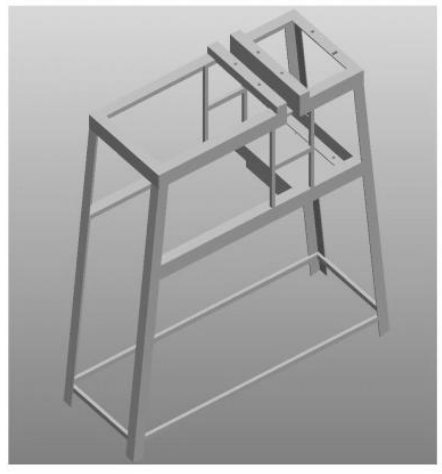

Fig -7: Frame

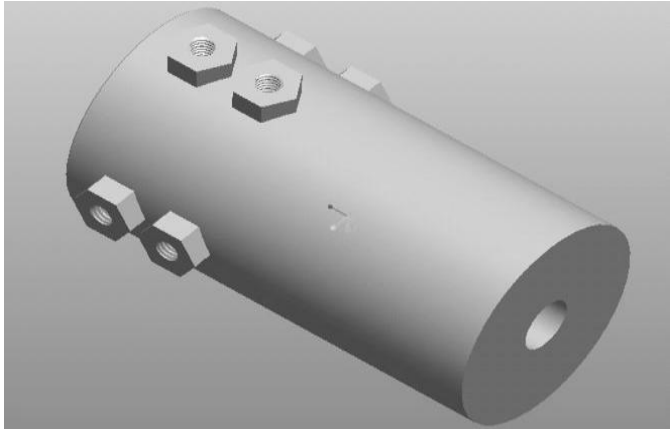

Fig -8: Main head

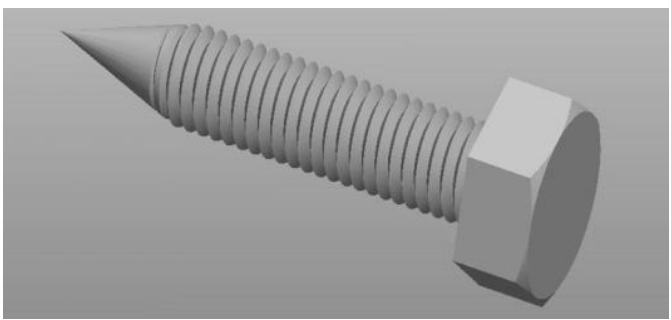

Fig -9: Teeth

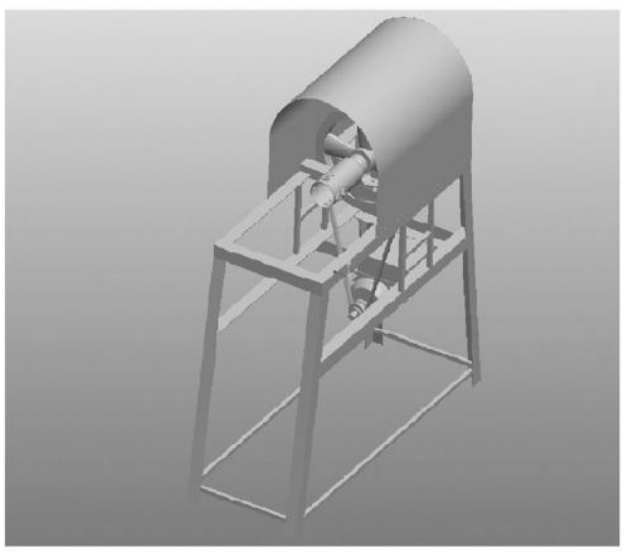

Fig -10: Assembly

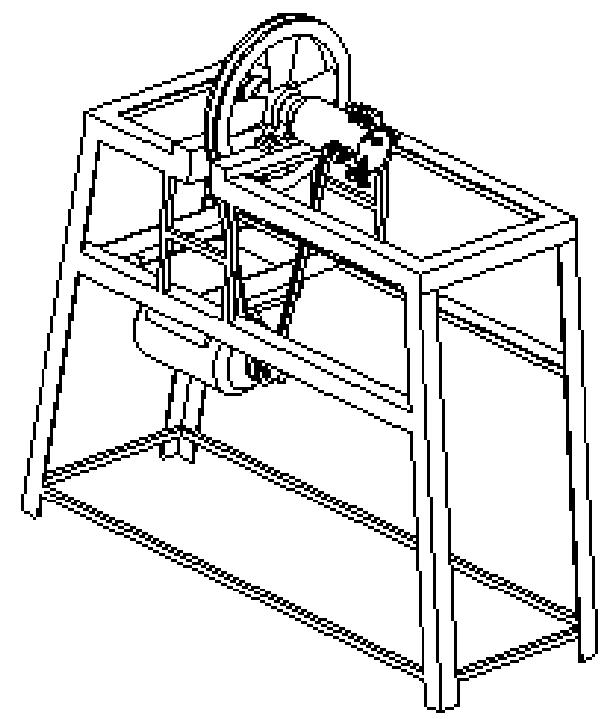

Fig -11: Isometric view 


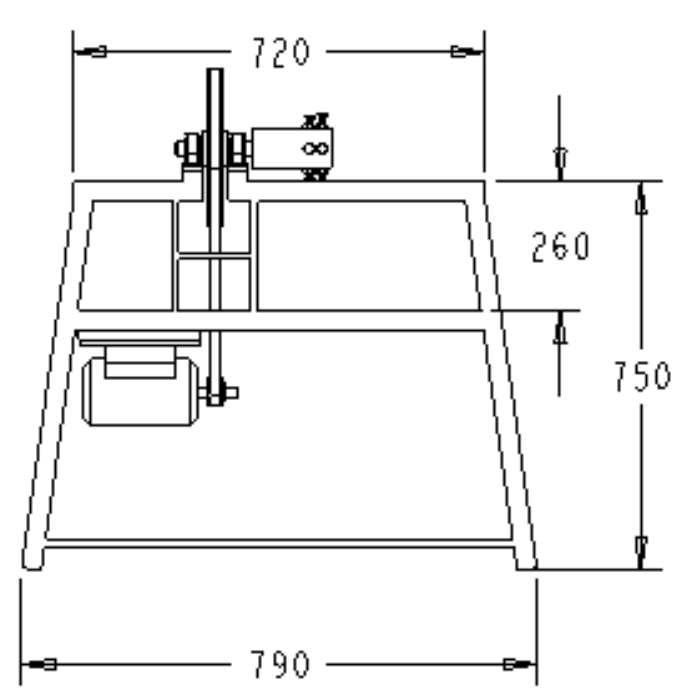

Fig 12: Front view

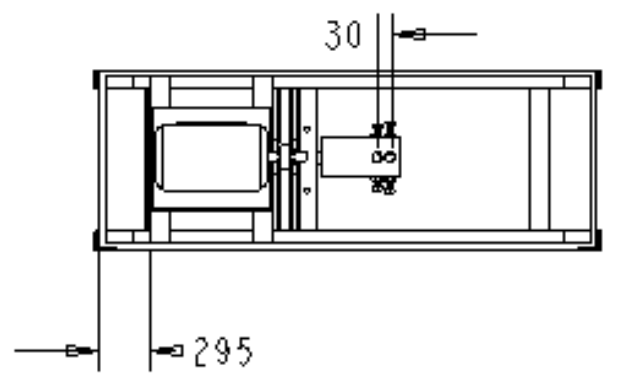

Fig -13: Top view

\section{SELECTION \& DESIGN CRITERIA}

General Requirements of Machine Design

$>\quad$ High productivity.

$>\quad$ Ability to produce and provide required accuracy of shape and size and also necessary surface finish.

Simplicity of design.

$>\quad$ Safety and convenience of control

$>\quad$ Low Cost.

$>$ Good Appearance.

\subsection{Design Procedure}

Before proceeding to the process of manufacturing, it's necessary to have some knowledge about the project design essential to design the project before starting the manufacturing. Maximum cost of producing a product is established originally by the designer.

General Design procedure for a product:

When a new product or their elements are to be designed, a designer may proceed as follows:

1. Make a detailed statement of the problems completely; it should be as clear as possible \& also of the purpose for which the machine is to be designed

2. Make selection of the possible mechanism which will give the desire motion.

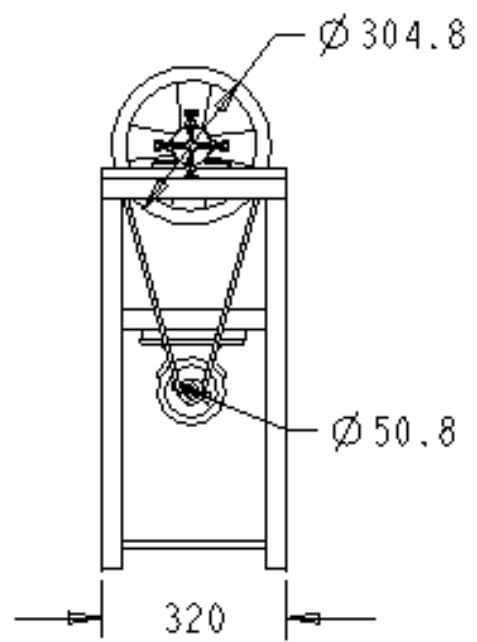

Fig -14: Side view

3. Determine the forces acting on it and energy transmitted by each element of the Machine

4. Select the material best suited for each element of the machine.

5. Determine the allowable or design stress considering all the factors that affect the Strength of the machine part.

6 . Identify the importance and necessary and application of the machine.

7. Problems with the existing requirement of the machine, productivity and demand.

8. Determine the size of each element with a view to prevent undue distortion or breakage under the applied load.

9. Modify the machine element or parts to agree with the past experience and judgment and to facilitate manufacture.

10. Make assembly and detail drawings of machine with complete specification for the materials and manufacturing methods i.e. accuracy, Surface finish etc [4].

\section{DESIGN CALCULATIONS}

\subsection{Design of Shaft}

A solid shaft rotating at $1450 \mathrm{rpm}$ is assumed to be made of mild steel. The shaft here is subjected to both bending moment and torsion stresses. The ultimate shear stress of a mild steel shaft from design data is $265 \mathrm{Mpa}$. The safe load is $300 \mathrm{~N}$ (Approx $30 \mathrm{Kg}$ ). The shaft of length $170 \mathrm{~mm}$ is subjected to bending moment and torsion stresses.

Maximum Bending moment about bearing

$\mathrm{BM}=300 \times 170$

$=51000 \mathrm{~N}-\mathrm{mm}$

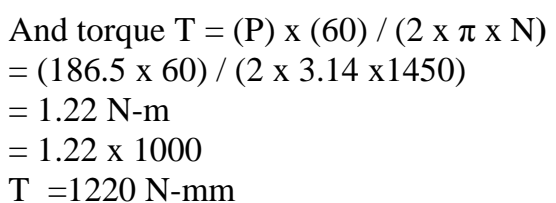

The diameter of shaft taken is $25 \mathrm{~mm}$ which is safe. 


\subsection{Design of Pulley}

Length of belt between driving shaft and driven shaft

$\mathrm{d}=$ diameter of driving pulley $=50.8 \mathrm{~mm}$

$\mathrm{D}=$ diameter of driven pulley $=304.8 \mathrm{~mm}$

$\mathrm{C}=$ central distance between driving \& driven pulley $=500 \mathrm{~mm}$

Length of belt

$\mathrm{L}=л(\mathrm{r} 1+\mathrm{r} 2)+2 \mathrm{X}+(\mathrm{r} 2-\mathrm{r} 1)^{2} / 2 \quad$...(5.2)

$\mathrm{L}=л(25.4+152.4)+2 \times 500+(152.4-25.4)^{2} / 2$

$\mathrm{L}=1591.07 \mathrm{~mm}$.

Selection of motor

A two phase motor of $0.25 \mathrm{hp}$ running at $1450 \mathrm{rpm}$ is chosen based on the load conditions.

The motor is prime drive in the machine it converts electrical power into mechanical power. It gives rotary motion to mechanism. The motor design is a very important design aspect in machine design practice.

To calculate the power

$\mathrm{P}=(2 \pi \mathrm{NT} / 60)$

$(0.25 \times 746)=(2 \pi \times 1450 \times \mathrm{T} / 60)$

$\mathrm{T}=(186.5 \times 60 \times 1000 / 2 \pi \times 1450)$

$\mathrm{T}=(186.5 \times 60 \times 1000 / 2 \pi \times 1450)$

$\mathrm{T}=1228.23 \mathrm{~N}-\mathrm{mm}$

\subsection{Design of Angles:-}

Due to the load of plate, job and filing force, the angle-link may buckle in two planes at right angle to each other. For buckling in the vertical plane (i.e.in the plane of the links), the links are considered As hinged at the middles and for buckling in a plane perpendicular to the vertical plane, it is considered as fixed at the middle and the both the ends.

Here, The maximum load due to above factors $=50 \mathrm{~kg}$ (including friction)

$\mathrm{F}=50 \mathrm{~kg}=50 \times 9.81=490.5 \mathrm{~N}$.

We know that the load on each link,

$\mathrm{F} 1=490.5 / 4=122.625 \mathrm{~N}$.

Assuming a factor of safety as 3, the links must be designed for a buckling load of

$\mathrm{Wcr}=122.625 \times 3=367.875 \mathrm{~N}$

Let $\mathrm{t} 1=$ Thickness of the link

b1 $=$ width of the link

So, cross sectional area of the link $=\mathrm{A}=\mathrm{t} 1 \mathrm{x}$ b1

Assuming the width of the link is three times the thickness of the link, i.e.b1 $=3 \times \mathrm{t} 1$

Therefore

$$
\mathrm{A}=\mathrm{t} 1 \mathrm{x} 3 \mathrm{t} 1=3 \mathrm{t} 1^{2}
$$

And moment of inertia of the cross section of the link,

$\mathrm{I}=1 / 12 \mathrm{t} 1 \mathrm{~b} 1^{3}$

$=2.25 \mathrm{tr}^{4}$
We know that $\mathrm{I}=\mathrm{AK}^{2}$, where $\mathrm{k}=$ radius of gyration.

$$
\mathrm{K}^{2}=\mathrm{I} / \mathrm{A}=2.25 \mathrm{t} 1^{4} / 3 \mathrm{t} 1^{2}=0.75 \mathrm{t} 1^{2}
$$

Since for the buckling of the link in the vertical plane, the ends are considered as hinged,

Therefore, the equivalent length of the link $\mathrm{L}=1=600 \mathrm{~mm}$.

And Rankin's constant, $\mathrm{a}=1 / 7500$

Now using the relation,

f x A

$\mathrm{Wcr}=$

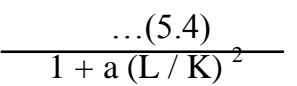

with usual notation,

Here stress-f $=100 \mathrm{~N} / \mathrm{mm}^{2}$

$367.875=$ $100 \times 3 \times t 1^{2}$

$367.875=$ $1+(1 / 7500) \quad\left(600^{2} / 0.75 \mathrm{t} 1^{2}\right)$

$300 \mathrm{t} 1^{4}-367.875 \mathrm{t}^{2}-64 \times 367.875=0$

$300 \mathrm{t}^{4}-367.875 \mathrm{t}^{2}-64 \times 367.875=0$

$\mathrm{t}^{2}=26.20$

$\mathrm{t} 1=5.1 \mathrm{~mm}$

$\mathrm{b} 1=3 \times \mathrm{t} 1=3 \times 5.1=15.35 \mathrm{~mm}$.

But the standard angle available of $35 \times 35$ x $5 \mathrm{~mm}$. Hence considering the safety aspect it has been selected. This can bear the impact loading. Hence the design is safe [5, 6].

\subsection{Design of Bearing}

Depending upon the nature of contact the antifriction bearing has been chosen.

\section{MATERIAL \& MANUFACTURING}

Since the rolling element is subjected to the high local stresses the material used is high carbon steel which has high quality .The material for both ball and races are heat treated to give extra hardness and treatment. These are manufactured by hot forged and then heat treated, ground and polished.

\subsection{Collector:}

The collector works as a storage part for the corn grains. The collector usually collects the corn grains which are thrown after breaking. The capacity of the collector determines the quantity of grains taken by it. It is circular in shape \& can be easily removed and fitted. 


\subsection{Metal Frame}

The metal frames used are angle iron bars. This type of frame is used for various purposes in engineering industry; it is also known as L-shaped frame. The material used for the frame is mild steel. It has carbon ranging from $0.10-0.20 \%$, Tensile strength is $420 \mathrm{~N} / \mathrm{mm}^{2}$. The frame is used as the main structure, which supports the magnetic assembly. It also supports the collector and the shaft having gears and bearing assembly. The metal plate-carrying shaft is welded to the frame. The handle is welded to the top of the frame. The metal frame is cut as per the requirements and then they are welded. The dimensions of the frame are as shown in the figure.

\section{FABRICATION}

The following parts were fabricated using the material and process shown below.

1. L angle ( $35 \times 35 \times 5 \mathrm{~mm})$

Material: Mild steel

Operation: Cutting, welding \& Drilling.

2. Shaft

Material: Mild steel

Operation: Facing, Planing, steeping,

3. Metal plate:

Material: Mild steel

Operation: Marking, Cutting \& Welding

4. Base Support

Material: Mild steel

Operation: Marking, Bending \& Cutting.

5. Bearing Support

Material: Wood

Operation: Marking, cutting, Drilling.

6. Pulleys

Material: Grey Casting

Operation: Boring, Fitting.

7. Bearing

Material: Grey Casting

Operation: Fitting.

8. Motor Plate

Material: wood

Operation: Marking, Cutting, Drilling.

\section{COST ESTIMATION}

Cost estimation may be defined as the process of forecasting the expenses that must be incurred to manufacture a product. These expenses take into a consideration all expenditure involved in a design \& manufacturing with all related service facilities such as pattern making, tool, making as well as a portion of the General Administrative \& selling costs.

\subsection{Purpose of Cost Estimating}

Basically the cost estimation is of two types: -

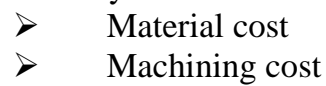

\subsection{Material Cost Estimation}

Material cost estimation gives the total amount required to collect the raw material which has to be processed or fabricated to desired size and functioning of the components. These materials are divided into two categories.

a. Material for Fabrication: In this the material in obtained in raw condition and is manufactured or processed to finished size for proper functioning of the component.

b. Standard Purchased Parts: This includes the parts which was readily available in the market like Allen screws etc .A list in for-chard by the estimation stating the quality, size \& standard parts, the weight of raw material and cost per $\mathrm{kg}$ for the fabricated parts.

\subsection{Machining Cost Estimation}

This cost estimation is an attempt to forecast the total expenses that may include manufacturing apart from material cost. Cost estimation of manufactured parts can be considered is judgment on and after careful consideration which includes Labor, Material and Factory services required to produce the required part.

\subsubsection{Procedure for Calculation of Material Cost}

The general procedure for calculation of material cost estimation is:

After designing a project a bill of material is prepared which is divided into two categories.

$>\quad$ Fabricated components.

$>\quad$ Standard purchased components.

The rates of all standard items are taken and added up. Cost of raw material purchased taken and added up.

\subsection{Cost Incurred}

Table -1: Bill of Material

\begin{tabular}{|c|c|c|c|c|}
\hline \multicolumn{5}{|c|}{ Materials Cost } \\
\hline $\begin{array}{l}\text { SL } \\
\text { No }\end{array}$ & Particulars & Material & Quantity & $\begin{array}{l}\text { Cost in } \\
\text { Rs }\end{array}$ \\
\hline 1 & Motor & - & 1 nos & 2500 \\
\hline 2 & L-angle (30kg) & MS & 1nos & 1560 \\
\hline 3 & Main Head & MS & 1nos & 170 \\
\hline 4 & Big Pulley & CI & 1nos & 420 \\
\hline 5 & Small Pulley & $\mathrm{CI}$ & 1nos & 70 \\
\hline 6 & Belt & - & 1nos & 320 \\
\hline 7 & Nut, bolt \& studs & MS & - & 470 \\
\hline 9 & Teeth & MS & 8 nos & 320 \\
\hline 10 & Shaft & MS & 1nos & 390 \\
\hline 11 & Pedestal Bearing & $\mathrm{CI}$ & 2 nos & 340 \\
\hline 12 & Screener & MS & 1nos & 350 \\
\hline 13 & Electricals & - & - & 300 \\
\hline \multicolumn{5}{|c|}{ Process Cost } \\
\hline 1 & Machining & - & - & 1000 \\
\hline
\end{tabular}




\begin{tabular}{|l|l|l|l|l|}
\hline 2 & Drilling & - & - & 300 \\
\hline 3 & Grinding/Filling & - & - & 150 \\
\hline 4 & Welding & - & - & 700 \\
\hline 5 & Greasing & - & - & 50 \\
\hline 6 & Painting & - & - & 580 \\
\hline 7 & Miscellaneous & - & - & 1200 \\
\hline \multicolumn{2}{|l}{ Total cost } & Rs \\
\end{tabular}

\section{ADVANTAGES}

- $\quad$ The power consumption is less.

- $\quad$ Easy in operation.

- Low cost

- Simple construction.

- Adaptable.

- Performance.

- $\quad$ Easy to setup

- $\quad$ Light weight.

- $\quad$ Easy maintenance.

\section{APPLICATIONS}

The machine can be used to peel the corn grains.

- Used in agriculture industries.

- Used in mills.

- The device can be very helpful to small scale farmers and domestic purpose.

\section{FUTURE SCOPE OF THE PROJECT}

The work has been a real challenge to execute as there were many practical design and fabrication problems along with cost constraints. The machine has a great future scope in any industry and for farmers due to its ease of use, moderate cost and simple design. The main constraint of this device is the slightly higher initial cost but the advantage lies in its low operating costs. Savings resulting from the use of this device will make it pay for itself within the short period of time.

\section{CONCLUSIONS}

The de-seeding machine has been designed, developed and fabricated keeping in mind the constraints and requirements of the Indian farmers. The deseeding machine was tested in the machine shop and later taken to the field. It worked well in the field conditions and gave an output of $45 \mathrm{Kg} /$ hour. The maneuverability of the device is quite good and the handling is quite simple. The seed discharging mechanism is effective and corn seeds can be discharged off very easily.

For commercial purpose one can improve the efficiency of the device effectively by increasing the size of the device and providing it with multiple heads. Additionally, the deseeder is a multifunctional machine that can de-seed various types of food item such as rice, chilly powering, potato past, corn de-husking etc. This can be done by changing the drum and teeth.

\section{ACKNOWLEDGEMENTS}

We are grateful to KSCST, Bangalore for providing financial support in selecting and developing the machine. We are thankful to Sagar, Pavan, Somnath and Vinayak for providing their help in completing the work. We are also thankful to the machine shop staff for the help provided in fabrication.

\section{REFERENCES}

[1]. www.agroproductlimited.com

[2]. http://zzaimeishi.en.alibaba.com/product/611124799213388518/Sweet_corn_deseeding_machine_0086_136138 47731.html.

[3]. http://www.vidhataindia.com/maze_sheller.htm.

[4].V.B.Bhandari, Design of machine elements, Third edition, Tata McGraw Hill Education private limited, New Delhi.

[5]. R.S. Khurmi \& B.C.Guptha, Theory of Machines, Eurasia publishing house pvt ltd., First edition, 1976.

[6]. K.Lingaiah, Machine design data hand book, Volume 1, Third edition, 2004.

\section{BIOGRAPHIES}

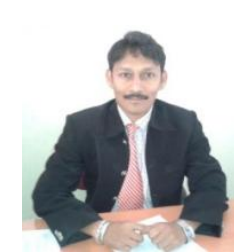
agriculture.

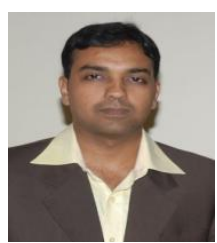

Mr. Anant J. Ghadi is a faculty member in the Dept of Mechanical Engineering, Maratha Mandal Engineering College, Belgaum. His areas of interest include machine design, manufacturing technology and its applications to

Dr.Arunkumar $\mathrm{P}$ is a faculty member in the Dept of Mechanical Engg, KLS Gogte Institute of Technology, Belgaum. His research areas include $\mathrm{CAD} / \mathrm{M}$, CAPP, Manufacturing technology. $\mathrm{He}$ has 10 publications to his credit. 